\title{
Construction and Study of Hetreojunction Solar Cell Based on Dodecylbenzene Sulfonic Acid-Doped Polyaniline/n-Si
}

\author{
I. Morsi, ${ }^{1}$ Sh. Ebrahim, ${ }^{2}$ and M. Soliman ${ }^{2}$ \\ ${ }^{1}$ Electronics and Communications Department, Arab Academy for Science, Technology and Maritime Transport, \\ P.O. Box 1029, Alexandria, Egypt \\ ${ }^{2}$ Department of Materials Science, Institute of Graduate Studies and Research, Alexandria University, P.O. Box 832, Alexandria, Egypt
}

Correspondence should be addressed to I. Morsi, drimanmorsi@yahoo.com

Received 1 March 2012; Accepted 16 May 2012

Academic Editor: Panagiotis Lianos

Copyright ( 2012 I. Morsi et al. This is an open access article distributed under the Creative Commons Attribution License, which permits unrestricted use, distribution, and reproduction in any medium, provided the original work is properly cited.

\begin{abstract}
Polyaniline/n-type Si heterojunctions solar cell are fabricated by spin coating of soluble dodecylbenzene sulfonic acid (DBSA)doped polyaniline onto $\mathrm{n}$-type Si substrate. The electrical characterization of the Al/n-type Si/polyaniline/Au (Ag) structure was investigated by using current-voltage $(I-V)$, capacitance-voltage $(C-V)$, and impedance spectroscopy under darkness and illumination. The photovoltaic cell parameters, that is, open-circuit voltage $\left(V_{\mathrm{oc}}\right)$, short-circuit current density $\left(J_{\mathrm{sc}}\right)$, fill factor $(\mathrm{FF})$, and energy conversion efficiency $(\eta)$ were calculated. The highest $J_{\mathrm{sc}}, V_{\mathrm{oc}}$, and efficiency of these heterojunctions obtained using PANI-DBSA as a window layer (wideband gap) and $\mathrm{Au}$ as front contact are $1.8 \mathrm{~mA} / \mathrm{cm}^{2}, 0.436 \mathrm{~V}$, and $0.13 \%$, respectively. From Mott-Schottky plots, it was found that order of charge carrier concentrations is $3.5 \times 10^{14}$ and $1.0 \times 10^{15} / \mathrm{cm}^{3}$ for the heterojunctions using $\mathrm{Au}$ as front contact under darknessness and illumination, respectively. Impedance study of this type of solar cell showed that the shunt resistance and series resistance decreased under illumination.
\end{abstract}

\section{Introduction}

Recently polymer semiconductor materials have been investigated due to their attractive applications in optoelectronic devices, such as organic thin-film transistors, photovoltaic cells, and organic light-emitting diodes $[1,2]$. Electrical conductivities of conjugated polymers can be varied over the full range from insulator to semiconductor and to metal according to doping type. As a result, a lot of research work has been carried out on the use of conducting polymers as active materials in electronic devices. Many of the useful properties of $\mathrm{p}-\mathrm{n}$ junction can be achieved by forming an appropriate semiconductor polymer-metal contact [3-5].

Polyaniline has received much attention due to its interesting, electrical, electrochemical, optical properties, and environmental stability. The conductivity of PANI depends on two variables, the degree of oxidation and the degree of protonation. It is known that, a large increase in the electrical conductivity can be obtained by treating the polyaniline base with aqueous acid [6]. Early articles on PANI/crystalline Silayer structure heterojunctions were fabricated [7-9]. These diodes present a great potential as radiation or gas sensors. In our previous study, solar cells have been reported by spin-coating polyaniline base (PANI-EB) over an n-type Si-substrate, and the final heterojunction's device structure was $\mathrm{Al} / \mathrm{n}$-type $\mathrm{Si} / \mathrm{PANI}-\mathrm{EB} / \mathrm{Au}$. It was found that heterojunctions fabricated using PANI-EB dissolved in N-methyl2-pyrrolidone, dimethylformamide, and tetrahydrofuran produced $J_{\text {sc }}$ equal to $10 \mathrm{~mA} / \mathrm{cm}^{2}, 5.123 \mathrm{~mA} / \mathrm{cm}^{2}$, and $2.78 \mathrm{~mA} / \mathrm{cm}^{2}$, respectively. Wang and Schiff, recently, have fabricated heterojunction solar cells using $\mathrm{HCl}$-doped polyaniline on crystalline n-type $\mathrm{Si}$ and found that open circuit voltage for these cells with high-conductivity PANI saturated at $0.51 \mathrm{~V}[10]$.

The aim of this work is to fabricate a layered structure heterojunction solar cell using n-type $\mathrm{Si}$ and polyaniline doped with DBSA. The effects of gold or silver as metallic grid front electrodes were investigated. $J-V, C-V$, and impedance characteristics were measured under darknessness and illumination to calculate and compare the electronic parameters of this heterojunction solar cell. 


\begin{tabular}{|c|}
\hline Au or Ag front contact \\
\hline Polyaniline-DBSA \\
\hline $\mathrm{n}-\mathrm{Si}$ \\
\hline $\mathrm{Al}$ back contact \\
\hline
\end{tabular}

FIGURE 1: Schematic of Al/n-Si/polyaniline-DBSA/Au or Ag heterojunction solar cell.

\section{Experimental Work}

2.1. Materials. Aniline (Loba Chemie, India) was purified by vacuum distillation before use, and ammonium persulphate, Isopropanol, and HF were purchased from Aldrich. Dodecylbenzene sulfonic acid (DBSA) was obtained from Oil Extractor Company (Egypt). The chloroform, methanol, dimethyl formamide (DMF), and diethyl ether solvent were bought from El-Gomhory Chemical Company (Egypt).

2.2. Preparation of Polyaniline and Fabrication of Al/n-Sil PANI Heterojunctions. Preparation of The chemical oxidative polymerization of aniline was carried out in an aqueous acidic solution using ammonium persulphate as an oxidizing agent [5]. The obtained polyaniline was doped with DBSA with $1: 3$ weight ratios and then dissolved in chloroform. Polished, phosphorus-doped, and $\{100\}$-oriented n-type silicon wafers ( $5 \mathrm{~cm}$ diam. and $300 \mu \mathrm{m}$ thick) were obtained from Monsanto Corp. The wafers of n-type silicon were ultrasonically cleaned in isopropanol and then dried at $150^{\circ} \mathrm{C}$. The wafers were etched in $\mathrm{HF}$ (40\%) to remove native oxide then rinsed in double distilled water and dried. Aluminum metal was deposited onto the back contact using vacuum coating machine (Edwards E306A).Thin layers (15 drops from $0.4 \mathrm{wt} \%$ ) of PANI doped with DBSA (PANI-DBSA) deposited onto the n-type silicon wafer by spin coating. The thickness of this layer was determined using scanning electron microscope to be 20 micron. The wafers were dried at $600^{\circ} \mathrm{C}$ for $10 \mathrm{~min}$. Gold or silver front grid contact was evaporated through a mechanical mask using the vacuum coating machine. The current-voltage characteristics were measured under both darkness and illumination conditions $\left(0.09 \mathrm{~W} / \mathrm{cm}^{2}\right)$ using Gamry G750 potentiostat/galvanostat with pilot integration controlled by PHE200 software. The level of illumination of tungsten halogen lamp was calibrated using Solarex standard solar cell.

The Mott-Schottky plots under darknessness and illumination were measured using Gamry G750 potentiostat/ galvanostat with pilot integration controlled by EIS300 software at $300 \mathrm{kHz}$ and room temperature. Impedance measurements under darknessness and different illumination level at zero bias were performed mainly in a frequency range from $0.1 \mathrm{~Hz}$ to $300,000 \mathrm{~Hz}$. The amplitude of the sinusoidal voltage signal $10 \mathrm{mV}$ was used and a bias voltage between -1.0 and $1.0 \mathrm{~V}$.

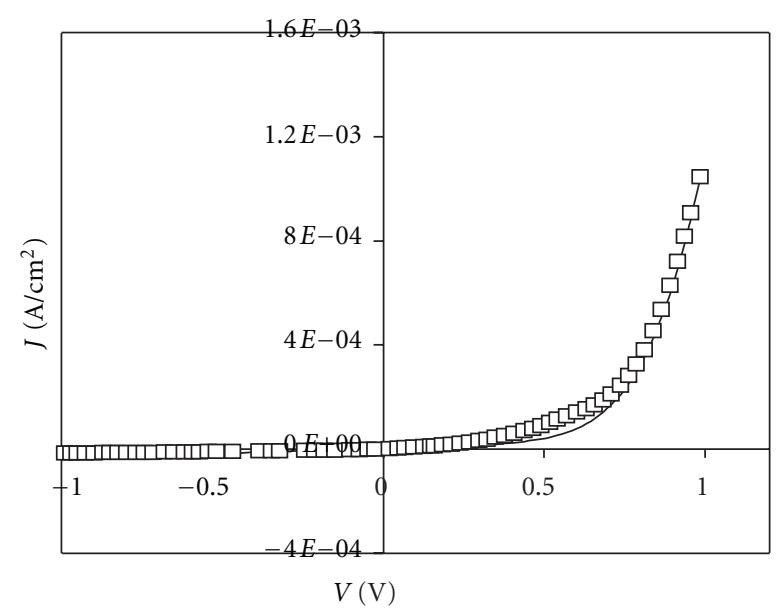

(a)

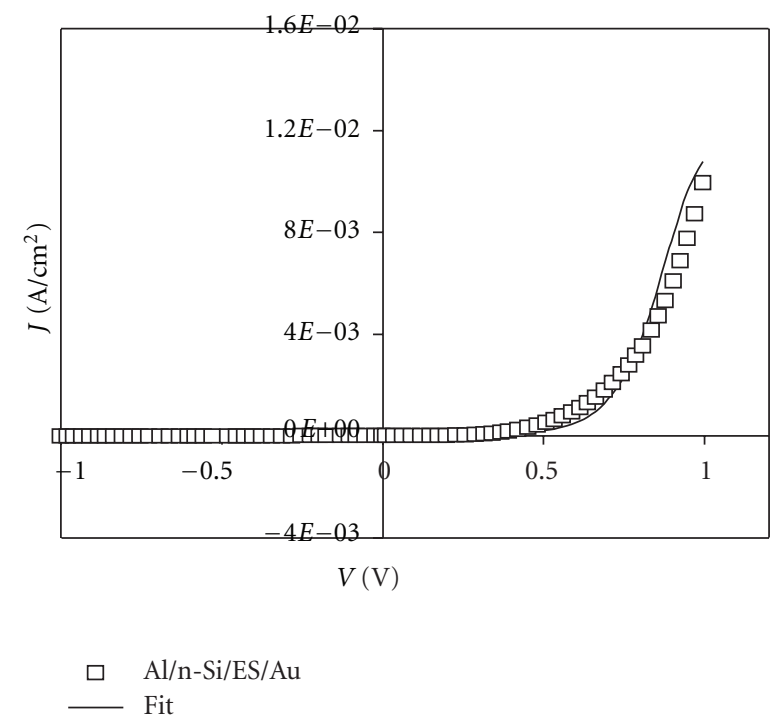

(b)

Figure 2: $J$ - $V$ characteristics for Al/PANI-DBSA/n-Si heterojunctions under darkness using $\mathrm{Au}$ or $\mathrm{Ag}$ as Ohmic contact. The solid line represents the expected $J-V$ behaviors.

\section{Results and Discussion}

3.1. J-V Characteristics for $\mathrm{Al} / \mathrm{n}$-Si/PANI-DBSA Heterojunction Solar Cell. The Schematic diagram of $\mathrm{Al} / \mathrm{n}-\mathrm{Si} /$ polyaniline heterojunctions is shown in Figure 1. Figures 2 and 3 show the current density-voltage characteristics for $\mathrm{Al} / \mathrm{n}$ $\mathrm{Si} / \mathrm{PANI}-\mathrm{DBSA}$ heterojunctions using Au or Ag as front electrode under darkness and illumination, respectively.

The $J-V$ curves can be separated into three regions: (i) at reverse bias and at forward bias up to about $0.6 \mathrm{~V}$, the characteristic is nearly symmetrical and is governed by a "leakage" current through the shunt resistance; (ii) at bias corresponding to flat-band conditions, the injection starts, and the exponential region can be distinguished; (iii) the saturation due to the series resistance is observed at higher bias. The $J-V$ curves of these heterojunctions cell under darkness conditions can be fitted to a Shockley equation 


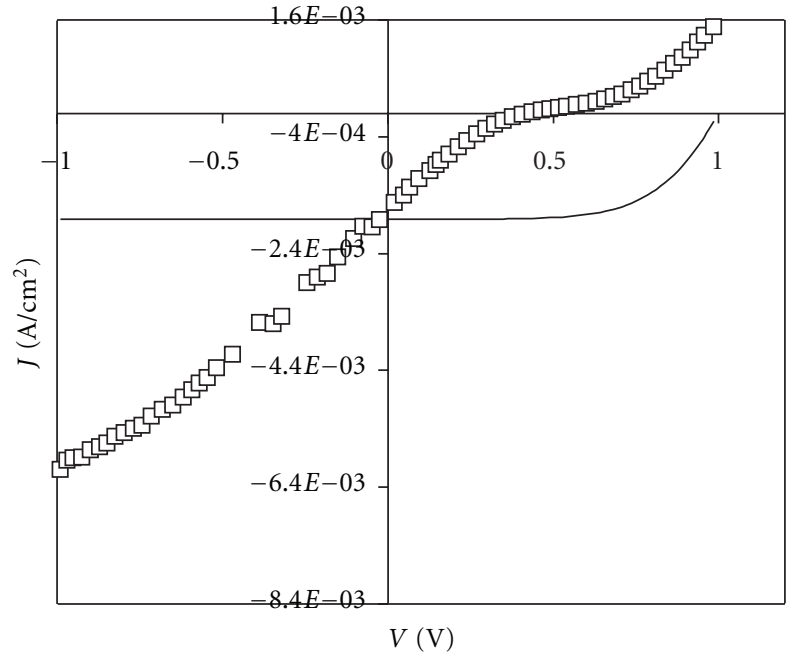

(a)

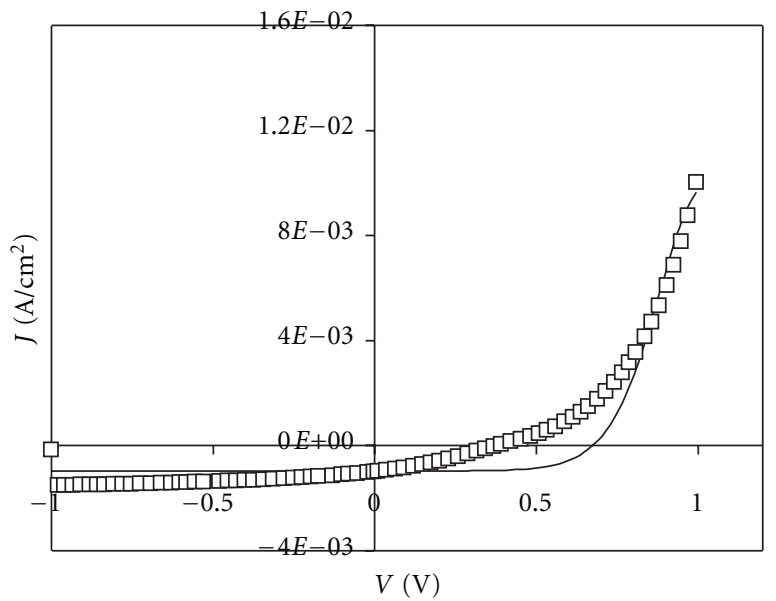

$\square \quad \mathrm{Al} / \mathrm{n}-\mathrm{Si} / \mathrm{ES} / \mathrm{Au}$

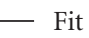

(b)

Figure 3: $J-V$ characteristics for Al/PANI-DBSA/n-Si heterojunctions under illumination $\left(0.09 \mathrm{~W} / \mathrm{cm}^{2}\right)$ using $\mathrm{Au}$ or $\mathrm{Ag}$ as Ohmic contact. The solid line represents the expected $J-V$ behaviors.

taking account of both the shunt and the series resistances of the cell [11]:

$$
J(V)=J_{0}\left[\exp \frac{q\left(V-J R_{s}\right)}{n k T}-1\right]+\frac{V-J R_{s}}{R_{\mathrm{sh}}},
$$

where $V$ is the applied voltage, $q$ is the elementary charge, $R_{s}$ is the cell series resistance, $R_{\mathrm{sh}}$ is the cell shunt resistance, $n$ is the diode ideality factor, and $J_{0}$ is the diode reverse saturation current. These parameters can be estimated using regressions analysis as shown in Table 1.

Under the illumination the heterojunctions solar cell can be described by the following equation:

$$
J(V)=J_{0}\left[\exp \frac{q\left(V-J R_{s}\right)}{n k T}-1\right]-J_{L},
$$

TABLe 1: Characteristic electronic parameters of $\mathrm{Al} / \mathrm{n}-\mathrm{Si} / \mathrm{PANI}-$ DBSA herterojunctions under darkness using $\mathrm{Au}$ or $\mathrm{Ag}$ as Ohmic contact.

\begin{tabular}{lcc}
\hline $\begin{array}{c}\text { Electronic } \\
\text { parameters }\end{array}$ & \multicolumn{2}{c}{ Ohmic contact } \\
\hline$R_{\mathrm{s}}(\Omega)$ & 70 & 18 \\
$R_{\mathrm{sh}}(\mathrm{k} \Omega)$ & 30 & 5 \\
$N$ & 4.36 & 2.75 \\
$J_{0}\left(\mathrm{~A} / \mathrm{cm}^{2}\right)$ & $3.1 \times 10^{-7}$ & $1.1 \times 10^{-7}$ \\
\hline
\end{tabular}

TABLE 2: Photovoltaic characteristic parameters of $\mathrm{Al} / \mathrm{n}-\mathrm{Si} / \mathrm{PANI}-$ DBSA herterojunctions using $\mathrm{Au}$ or $\mathrm{Ag}$ as Ohmic contact.

\begin{tabular}{lcc}
\hline $\begin{array}{l}\text { Electronic } \\
\text { parameters }\end{array}$ & \multicolumn{2}{c}{ Ohmic contact } \\
\hline$V_{\text {oc }}(\mathrm{V})$ & 0.436 & 0.4 \\
$J_{\mathrm{sc}}\left(\mathrm{mA} / \mathrm{cm}^{2}\right)$ & 1.8 & 0.974 \\
$V_{\mathrm{m}}(\mathrm{V})$ & 0.1359 & 0.168 \\
$J_{\mathrm{m}}\left(\mathrm{mA} / \mathrm{cm}^{2}\right)$ & 0.95 & 0.679 \\
$\mathrm{FF}$ & 0.197 & 0.29 \\
$\eta(\%)$ & 0.13 & 0.011 \\
\hline
\end{tabular}

where $J_{L}$ is photogenerated current density, $J=J_{L} \approx J_{\text {sc }}$ at $V=V_{0}$. The fit was carried out with the parameters derived from the darkness $J-V$ analysis and $J_{L}=J_{\text {sc }}$. The illuminated heterojunction solar cells have a lower fill factors (FF) than has been expected. The FF depends on $R_{s}, R_{\mathrm{sh}}$, and $n$ parameters.

The photovoltaic cell characteristics, that is, open-circuit voltage $\left(V_{\mathrm{oc}}\right)$, short-circuit current density $\left(J_{\mathrm{sc}}\right)$, fill factor $(\mathrm{FF})$, and energy conversion efficiency $(\eta)$ were calculated under illumination as shown in Table 2. The highest $J_{\text {sc }}$, $V_{\mathrm{oc}}$, and efficiency of these heterojunctions obtained using PANI-DBSA as a window layer and $\mathrm{Au}$ as front contact are $1.8 \mathrm{~mA} / \mathrm{cm}^{2}, 0.436 \mathrm{~V}$, and $0.13 \%$, respectively.

3.2. C-V Characteristics of Al/n-Si/PANI-DBSA Heterojunctions. Figures 4 and 5 illustrate Mott-Schottky plots at $300 \mathrm{kHz}$ for $\mathrm{Al} / \mathrm{n}-\mathrm{Si} / \mathrm{PANI}-\mathrm{DBSA}$ heterojunctions under darkness and illumination, respectively using $\mathrm{Au}$ or $\mathrm{Ag}$ as front electrode.

The linear relationship between $1 / C^{2}$ and reverse voltage indicates the formation of heterojunction between polyaniline and $\mathrm{n}$-Si. The reverse-bias capacitance measurements are made at high frequency $(300 \mathrm{kHz})$ so that the interface states are unable to respond to the ac signal. The capacitance $(C)$ of a Schottky barrier diode in the ideal case can be expressed as [12-14]:

$$
C^{-2}=\frac{2\left[V_{d}+V\right]}{q \varepsilon_{0} \varepsilon_{s} N S},
$$

where $V$ is the applied potential, $S$ is the active device area, $N$ is the carrier concentrations, $V_{d}$ is the diffusion potential, $\varepsilon_{0}$ is the permittivity of vacuum, and $\varepsilon_{s}$ is the relative dielectric constant of Si. It is observed that $1 / C^{2}$ versus $V$ plots 


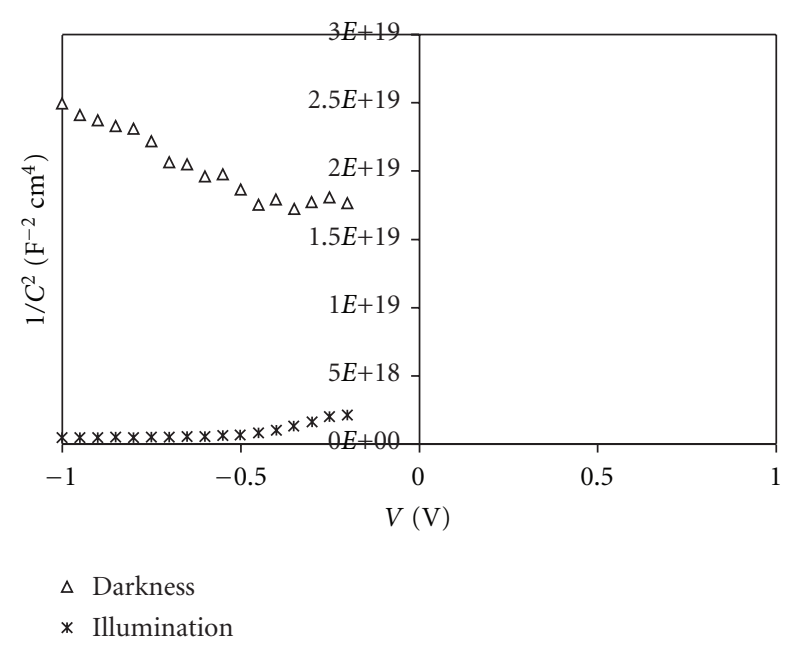

Figure 4: Mott-Schottky plots for Al/PANI-DBSA/n-Si/Au heterojunctions under darkness and illumination $\left(0.09 \mathrm{~W} / \mathrm{cm}^{2}\right)$.

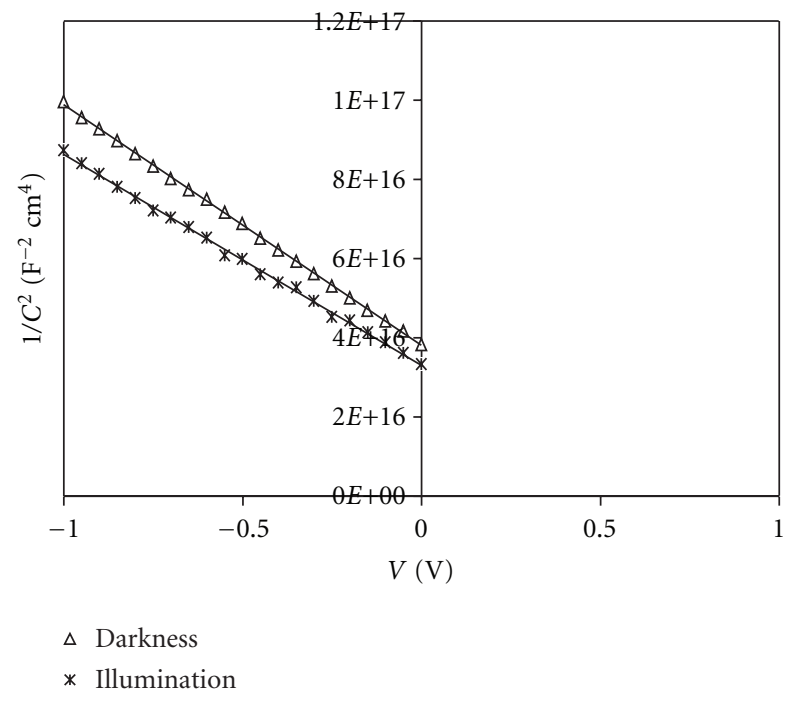

FIGURe 5: Mott-Schottky plots for Al/PANI-DBSA/n-Si/Ag heterojunctions under darkness and illumination $\left(0.09 \mathrm{~W} / \mathrm{cm}^{2}\right)$.

are linear in the reverse bias. Beyond this voltage, the plots are nonlinear due to the inhomogeneity of the charge carrier in the bulk of semiconductor and sets of traps at the interfaces. The carrier concentration can be determined from the slop of $C^{-2}$ versus $V$ plots. It is found that order of carrier concentrations is $3.5 \times 10^{14}$ and $1.0 \times 10^{15} / \mathrm{cm}^{3}$ for the heterojunctions using $\mathrm{Au}$ as front contact under darkness and illumination, respectively. This lowness of carrier concentrations explains the low quantity of $J_{\mathrm{sc}}$ and efficiency of the heterojunctions.

It is apparent that, generally, the capacitances of junction increase with illumination. This is a consequence of a reduced depletion width and built in potentials or diffusion potentials under light [15]. In addition, carrier concentrations are $5.8 \times 10^{16}$ and $7.0 \times 10^{16} / \mathrm{cm}^{3}$ for the

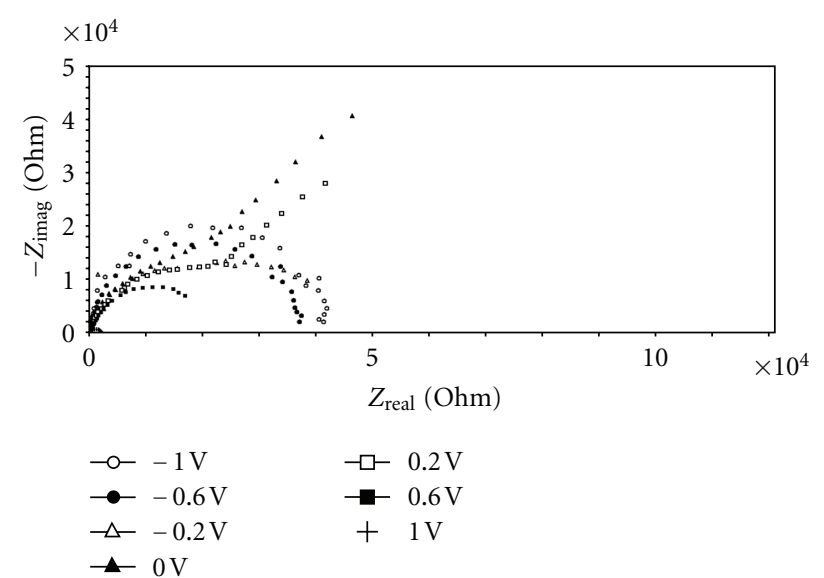

FIGURE 6: Nyquist impedance spectra of Al/n-Si/PANI-DBSA/Au heterojunctions under darkness at different potentials.

heterojunctions using $\mathrm{Ag}$ as front contact under darkness and illumination, respectively.

3.3. Impedance Spectroscopy. Impedance analysis method enables the reliable determination of the series resistance, shunt resistance, saturation current, and built in potential of nonideal semiconductor $\mathrm{p}-\mathrm{n}$ junctions [16]. Impedance spectroscopy is a technique for the electrical characterization by measuring the response of the materials to an applied ac signal.

According to this technique, the complex impedance of test sample, $Z$, which is expressed as $Z=Z^{\prime}-j Z^{\prime \prime}$, where $Z^{\prime}$ is the real part and $Z^{\prime /}$ is the imaginary part, is measured directly in the frequency domain. A plot of $Z^{\prime \prime}$ versus $Z^{\prime}$ on the complex plane for varying frequency gives the impedance spectrum of the test sample. From this, the equivalent circuit parameters which are representative of the physical processes taking place in the sample can be determined [17]. The impedance spectrum of a circuit with resistor $\left(R_{\mathrm{sh}}\right)$ and capacitance in parallel is a semicircle in the fourth quadrant about the real axis touching the origin, with a radius of $R / 2$ [18]. If the semicircle is away from the origin, it indicates the presence of series resistance in the network.

The Nyquist impedance spectra of Al/n-Si/PANIDBSA/Au heterojunctions under darkness and illumination $\left(0.09 \mathrm{~W} / \mathrm{cm}^{2}\right)$ are shown in Figures 6 and 7 , respectively at different potentials and are nearly a semicircle, indicating the predominance of a single time constant. The shunt resistance and series resistance as shown in Table 3 decrease under illumination, and this present evidence that the efficiency of this type of solar cell is limited by series and shunt resistance. The deviation from the perfect semicircle may be attributed to the variation of shun resistance and capacitance of herterojunctions at cell bias [18]. The impedance spectrum is shifted along the zero of real axis with increase applied bias due to decrease of series resistances.

The similar behavior was observed for $\mathrm{Al} / \mathrm{n}$-Si/PANIDBSA/Ag heterojunctions under darkness and illumination as shown in Figures 8 and 9, respectively at different 


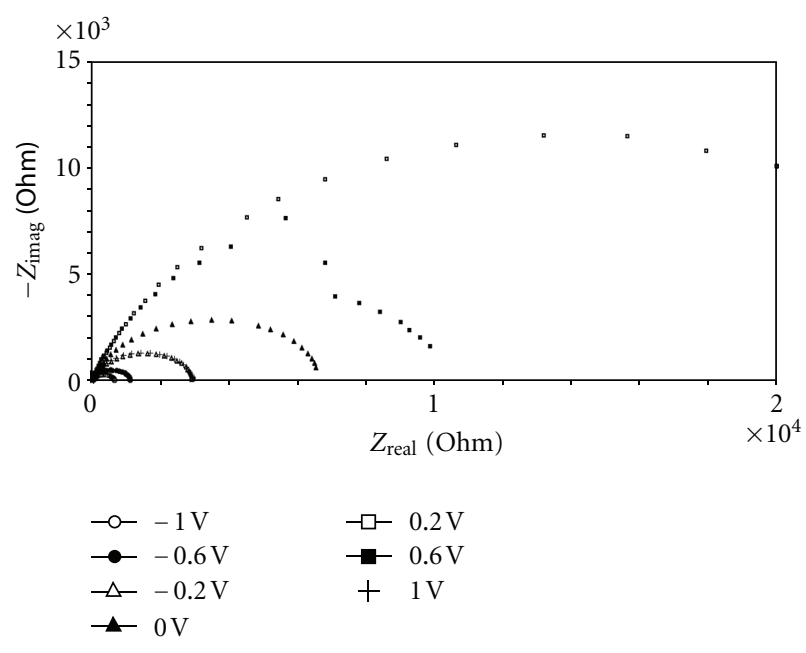

Figure 7: Nyquist impedance spectra of $\mathrm{Al} / \mathrm{n}-\mathrm{Si} / \mathrm{PANI}-\mathrm{DBSA} / \mathrm{Au}$ heterojunctions under illumination $\left(0.09 \mathrm{~W} / \mathrm{cm}^{2}\right)$ at different potentials.

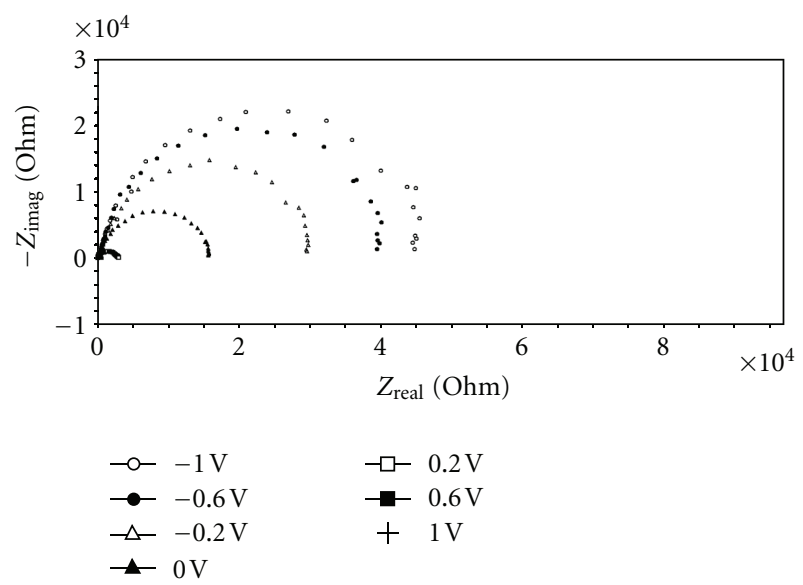

Figure 8: Nyquist impedance spectra of Al/n-Si/PANI-DBSA/Ag heterojunctions under darkness at different potentials.

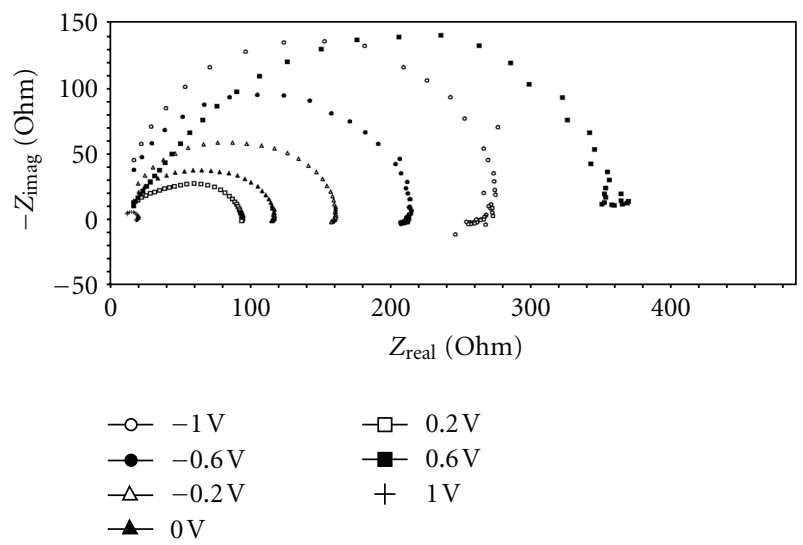

Figure 9: Nyquist impedance spectra of $\mathrm{Al} / \mathrm{n}-\mathrm{Si} / \mathrm{PANI}-\mathrm{DBSA} / \mathrm{Ag}$ heterojunctions under illumination $\left(0.09 \mathrm{~W} / \mathrm{cm}^{2}\right)$ at different potentials.
TABLE 3: Characteristic electronic parameters extracted from impedance spectroscopy of the herterojunctions under darkness and illumination.

\begin{tabular}{|c|c|c|}
\hline & \multicolumn{2}{|c|}{ Electronic parameters } \\
\hline & $\operatorname{Rs}(\Omega)$ & $\operatorname{Rsh}(\mathrm{k} \Omega)$ \\
\hline \multicolumn{3}{|c|}{ Al/n-Si/PANI-DBSA/Au (darkness) } \\
\hline$-1.0 \mathrm{~V}$ & 103 & 41 \\
\hline$-0.6 \mathrm{~V}$ & 88 & 37 \\
\hline$-0.2 \mathrm{~V}$ & 85 & 50 \\
\hline $0.0 \mathrm{~V}$ & 116 & 40 \\
\hline $0.2 \mathrm{~V}$ & 100 & 40 \\
\hline $0.6 \mathrm{~V}$ & 70 & 25 \\
\hline $1.0 \mathrm{~V}$ & 21 & 20 \\
\hline \multicolumn{3}{|c|}{ Al/n-Si/PANI-DBSA/Au (illumination) } \\
\hline$-1.0 \mathrm{~V}$ & 25 & 0.650 \\
\hline$-0.6 \mathrm{~V}$ & 19 & 1.1 \\
\hline$-0.2 \mathrm{~V}$ & 26 & 3 \\
\hline $0.0 \mathrm{~V}$ & 34 & 7 \\
\hline $0.2 \mathrm{~V}$ & 33 & 30 \\
\hline $0.6 \mathrm{~V}$ & 17 & 12 \\
\hline $1.0 \mathrm{~V}$ & 37 & 3 \\
\hline \multicolumn{3}{|c|}{ Al/n-Si/PANI-DBSA/Ag (darkness) } \\
\hline$-1.0 \mathrm{~V}$ & 57 & 50 \\
\hline$-0.6 \mathrm{~V}$ & 103 & 30 \\
\hline$-0.2 \mathrm{~V}$ & 92 & 45 \\
\hline $0.0 \mathrm{~V}$ & 69 & 16 \\
\hline $0.2 \mathrm{~V}$ & 18 & 3 \\
\hline $0.6 \mathrm{~V}$ & 12 & 0.57 \\
\hline $1.0 \mathrm{~V}$ & 8 & 0.024 \\
\hline \multicolumn{3}{|c|}{ Al/n-Si/PANI-DBSA/Au (illumination) } \\
\hline$-1.0 \mathrm{~V}$ & 0 & 0.274 \\
\hline$-0.6 \mathrm{~V}$ & 0 & 0.214 \\
\hline$-0.2 \mathrm{~V}$ & 9 & 0.16 \\
\hline $0.0 \mathrm{~V}$ & 10 & 0.116 \\
\hline $0.2 \mathrm{~V}$ & 5 & 0.095 \\
\hline $0.6 \mathrm{~V}$ & 10 & 0.067 \\
\hline $1.0 \mathrm{~V}$ & 7 & 0.019 \\
\hline
\end{tabular}

potentials. The impedance curves give a series and shunt resistance values different form those obtained from the $I-V$ measurements. This discrepancy can be explained by the different nature of the impedance and $I-V$ measurement techniques. If the solar cell is uniform and ideal, the two measurements yield the same value; otherwise, they will yield different values. This can be explained by the inhomogeneities (as a combination of the interfacial insulator layer composition, nonuniformity of the interfacial insulator layer thickness, and distribution of interfacial charges) that occur at Si/PANI-EB interface [19].

\section{Conclusions}

Polyaniline/n-type Si heterojunctions were fabricated by spin coating of soluble polyaniline on n-type Si substrate. $I-V$, 
$C-V$, and impedance spectroscopy under darkness and illumination were investigated for these herterojunctions. The photovoltaic cell parameters, that is, open-circuit voltage $\left(V_{\mathrm{oc}}\right)$, short-circuit current density $\left(J_{\mathrm{sc}}\right)$, fill factor $(\mathrm{FF})$, and energy conversion efficiency $(\eta)$ were calculated. The linearity of Mott-Schottky plots was indicated by, the formation of heterojunction between polyaniline and n-type $\mathrm{Si}$ and the slope of $1 / C^{2}$ versus voltage was changed under illumination. It was found that order of carrier concentrations is $3.5 \times 10^{14}$ and $1.0 \times 10^{15} / \mathrm{cm}^{3}$ for the heterojunctions using Au as front contact under darkness and illumination, respectively. The impedance spectrum of these herterojunctions is shifted along the zero of real axis with an increase-applied bias due to decrease of series resistances.

\section{Acknowledgments}

The authors would like to acknowledge the financial support of this work from Research Enhancement Program (ALEXREP), Alexandria University, Ministry of Higher Education, Egypt.

\section{References}

[1] Z. V. Vardenya, A. J. Heeger, and A. Dodabalapurc, "Fundamental research needs in organic electronic materials," Synthetic Metals, vol. 148, pp. 1-3, 2005.

[2] M. Yoshida, S. Uemura, T. Kodzasa, H. Ushijima, and T. Kamata, "High performance organic FET with double-semiconductor layers," Synthetic Metals, vol. 137, no. 1-3, pp. 893894, 2003.

[3] R. A. Nafdey and D. S. Kelkar, "Schottky diode using $\mathrm{FeCl}_{3}$ doped polyaniline," Thin Solid Films, vol. 477, no. 1-2, pp. 95100, 2005.

[4] Sh. Ebrahim, A. Gad, and A. Morsy, "Highly crystalline and soluble dodecylbenzene sulfonic acid doped poly(o-toluidine)," Synthetic Metals, vol. 160, no. 23-24, pp. 2658-2663, 2010.

[5] Sh. Ebrahim, "Fabrication of Schottky diode based on Zn electrode and polyaniline doped with 2-acrylamido-2-methyl1-propanesulfonic acid sodium salt," Journal of Polymer Research, vol. 16, no. 5, pp. 481-487, 2009.

[6] Sh. Ebrahim, A. H. Kashyout, and M. Soliman, "Ac and Dc conductivities of polyaniline/poly vinyl formal blend films," Current Applied Physics, vol. 9, no. 2, pp. 448-454, 2009.

[7] J. M. G. Laranjeira, H. J. Khoury, W. M. de Azevedo, E. F. da Silva, and E. A. de Vasconcelos, "Fabrication of high quality silicon-polyaniline heterojunctions," Applied Surface Science, vol. 190, no. 1-4, pp. 390-394, 2002.

[8] M. Sağlam, M. Biber, M. Çakar, and A. Türüt, "The effects of the ageing on the characteristic parameters of polyaniline/ptype Si/Al structure," Applied Surface Science, vol. 230, no. 1-4, pp. 404-410, 2004.

[9] A. Ashery, A. A. M. Farag, and M. A. Salem, "Fabrication and characterization of in situ polymerized n-polyaniline films grown on p-Si heterojunctions," Microelectronic Engineering, vol. 85, no. 11, pp. 2309-2315, 2008.

[10] W. Wang and E. A. Schiff, "Polyaniline on crystalline silicon heterojunction solar cells," Applied Physics Letters, vol. 91, Article ID 133504, 3 pages, 2007.

[11] K. Kawano, N. Ito, T. Nishimori, and J. Sakai, "Open circuit voltage of stacked bulk heterojunction organic solar cells,"
Applied Physics Letters, vol. 88, Article ID 073514, 3 pages, 2006.

[12] S. M. Sze, Physics of Semiconductor Devices, Wiley Eastern Limited, 3rd edition, 1985.

[13] D. Chirvase, Z. Chiguvare, M. Knipper, J. Parisi, V. Dyakonov, and J. C. Hummelen, "Temperature dependent characteristics of poly(3 hexylthiophene)-fullerene based heterojunction organic solar cells," Journal of Applied Physics, vol. 93, no. 6, pp. 3376-3383, 2003.

[14] E. H. Rhoderic and R. H. Williams, Metals Semiconductor Contacts, Oxford University Press, Oxford, UK, 2nd edition, 1988.

[15] G. Friesen, E. D. Dunlop, and R. Wendt, "Investigation of CdTe solar cells via capacitance and impedance measurements," Thin Solid Films, vol. 387, no. 1-2, pp. 239-242, 2001.

[16] A. Straub, R. Gebs, H. Habenicht et al., "Impedance analysis: a powerful method for the determination of the doping concentration and built-in potential of nonideal semiconductor $\mathrm{p}-\mathrm{n}$ diodes," Journal of Applied Physics, vol. 97, Article ID 083703, 8 pages, 2005.

[17] H. Bayhan and S. Ozden, "Measurement and comparison of complex impedance of silicon $\mathrm{p}-\mathrm{i}-\mathrm{n}$ photodiodes at different temperatures," Semiconductors, vol. 41, no. 3, pp. 353-356, 2007.

[18] R. A. Kumar, M. S. Suresh, and J. Nagaraju, "Facility to measure solar cell ac parameters using an impedance spectroscopy technique," Review of Scientific Instruments, vol. 72, no. 8, pp. 3422-3427, 2001.

[19] Sh. Ebrahim, "Impedance spectroscopy of heterojunction solar cell based on polyaniline base-equivalent circuit analysis," Polymer Science A, vol. 53, pp. 1217-1226, 2011. 


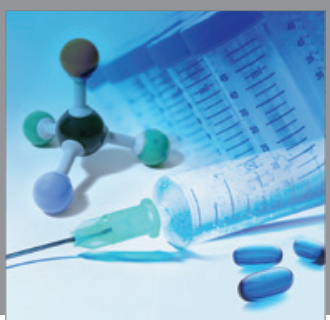

International Journal of

Medicinal Chemistry

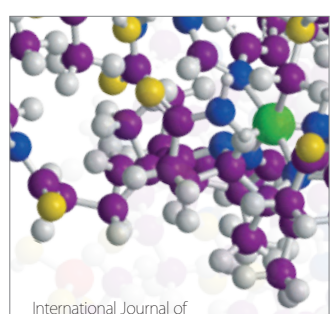

Carbohydrate Chemistry

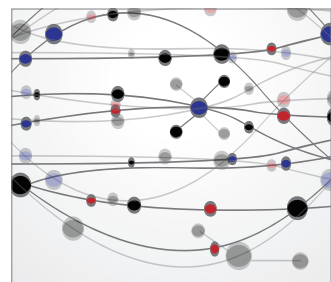

The Scientific World Journal
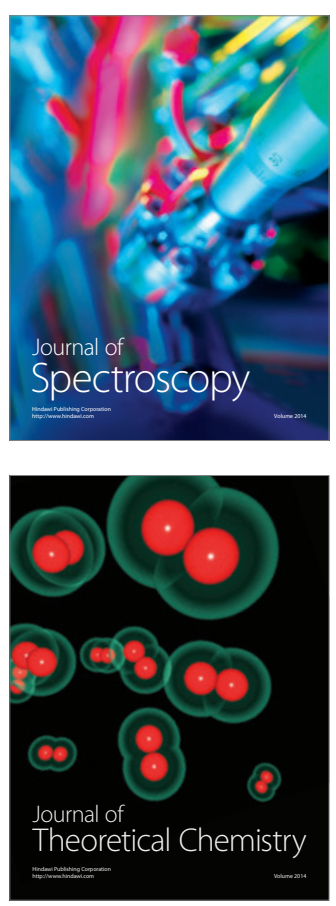
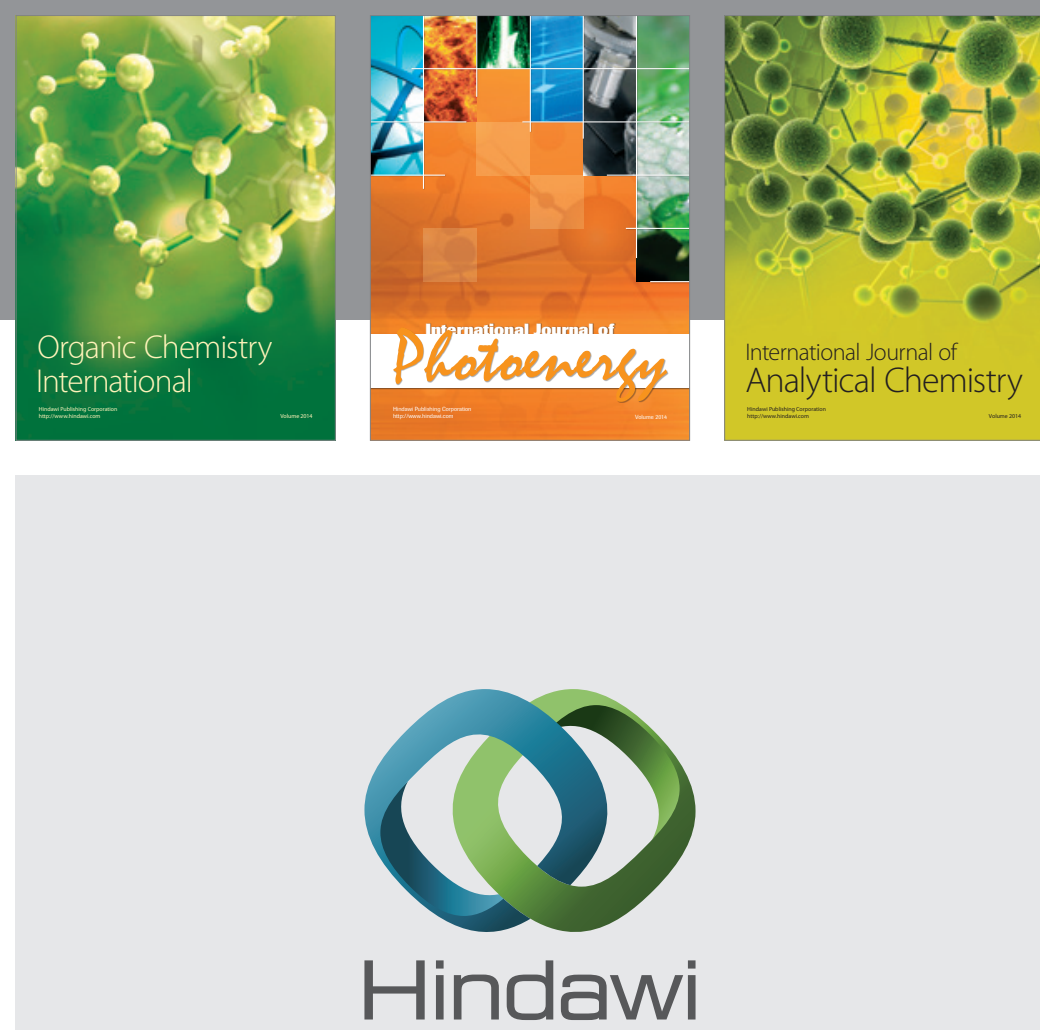

Submit your manuscripts at

http://www.hindawi.com
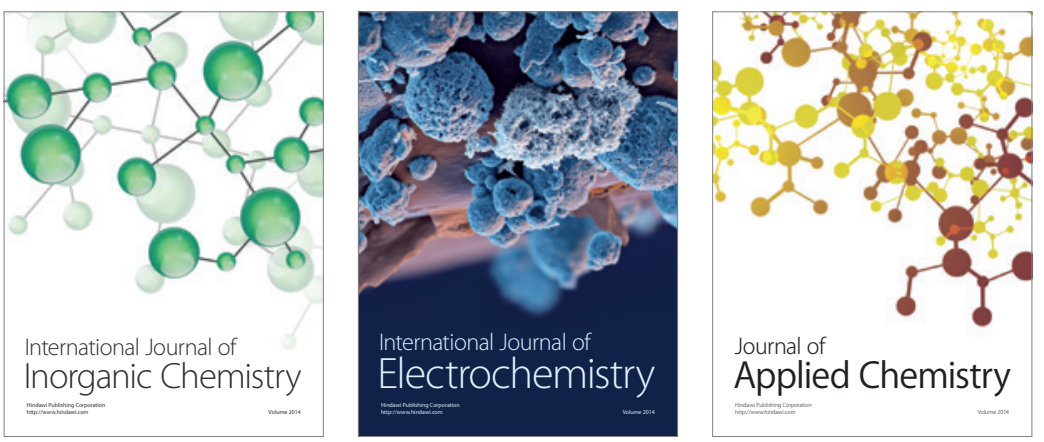

Journal of

Applied Chemistry
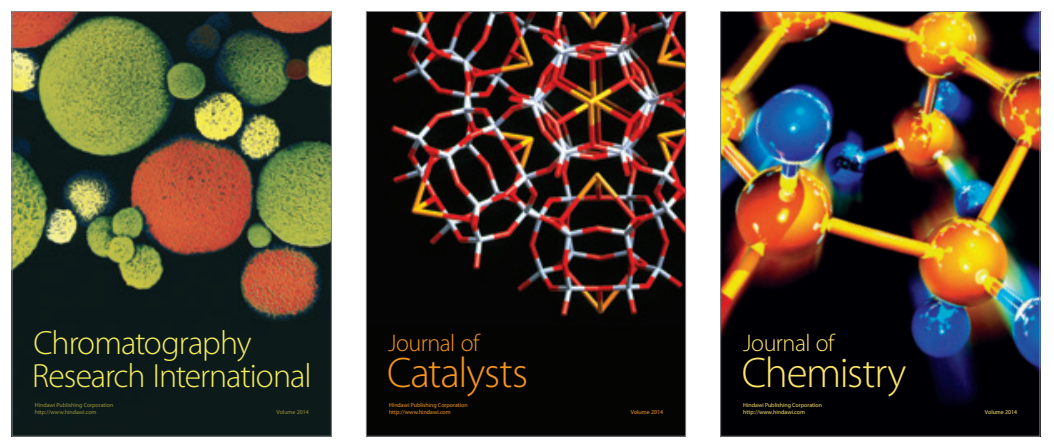
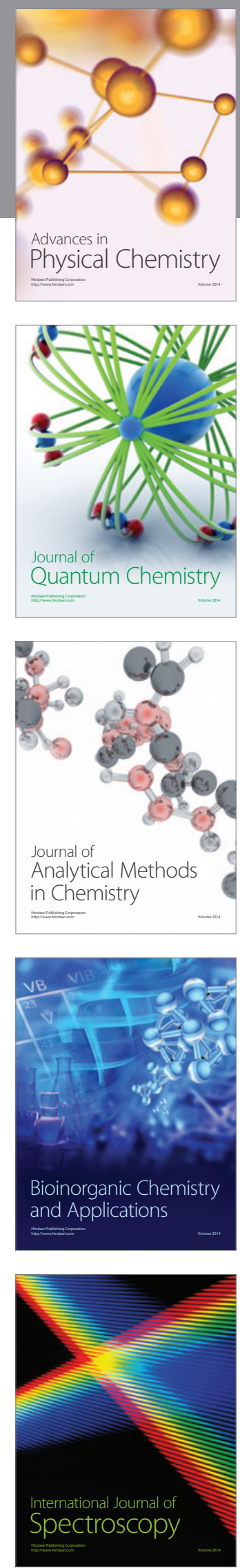